\title{
REPRESENTASI POLITIK PEREMPUAN PARTAI DEMOKRAT DALAM PEMILU LEGISLATIF 2014 DI SUMBAR Hanifa Muwahidah
}

Jurusan Ilmu Politik, Fakultas Ilmu Sosial Dan Ilmu Politik, Universitas Andalas Email : hanifamuwahidah97@gmail.com

\begin{abstract}
Abstrak
Representasi politik perempuan dalam perpolitikan di Indonesia dapat dilihat dalam partai politik yang dimana keterwakilan perempuan sudah diatur dalam Affirmative action yaitu keterwakilan $30 \%$ perempuan dalam partai. Partai politik Demokrat salah satu partai yang sudah memberikan keterwakilan perempuan 30\% dalam pencalonan anggota legislatif perempuan dalam pemilu. Pada pemilu 2014 walaupun Partai Demokrat sudah memberikan Keterwakilannya pencalonan perempuan dalam legilatif 30\% tetap saja pada hasil Pileg tersebut perempuan tidak memenangkan satu kursi pun dalam DPRD Sumatera Barat tahun 2014. Adapun tujuan dari penelitian ini adalah untuk melihat faktor-faktor yang mempengaruhi Representasi politik perempuan partai politik Demokrat dalam pemilu legislatif tahun 2014 tingkat Sumatera Barat. Dalam penelitian ini peneliti menggunakan metode Kualitatif dengan pendekatan Studi Kasus. Teori yang digunakan pada penelitian ini rekrutmen politik dari Rush dan Althof dan representasi politik perempuan dari Hanna Pitkin. Peneliti melihat adanya banyak faktor yang mengakibatakan turunnya perolehan suara yang di dapatkan oleh partai politik Demokrat dari pemilu 2009 ke 2014. Yang pertama dilihat dari rekrutmen yang dilakukan oleh partai demokrat, bagaimana representasi politik perempuan dalam partai, Dan adanya 4 faktor yang mengakibatkan hal tersebut, pertama turunnya elektabilitas partai politik Demokrat, yang terjadi diakibatkan habisnya masa SBY dalam pencalonan presiden dan buruknya citra partai demokrat dikarenakan para kader partai politik Demokrat di nasional terlibat kasus korupsi yang dimana hal tersebut membuat masyakarat kurang simpati terhadap partai. Selanjutnya tidak adanya perempuan diberikan no urut partai tinggi dalam dapil yang ketiga kurang aktifnya perempuan dalam berkampanye dan yang terakhir kurangnya sosialsasi tentang pemilu legislatif 2014 dan begitu juga dengan sosalisasi terhadap caleg perempuan.
\end{abstract}

Kata Kunci: Representasi Politik ; Keterwakilan Perempuan ; Pemilu 2014.

\begin{abstract}
Abstrack
Women's political representation in politics in Indonesia can be seen in political parties where women's representation is regulated in affirmative action, namely the $30 \%$ representation of women in parties. Demokrat political party is one of much party that has given women $30 \%$ representation in the nomination of women legislative members in elections. In the 2014 election, although the Demokrat Party had given its Representation to the nomination of women in 30\% legislative branch, the election results did not win a single seat in the West Sumatra $D P R D$ in 2014. Researchers found that there are many factors that contribute to the decline in votes obtained by the Demokrat party from the election in 2009 to 2014. The first qualification from the recruitment conducted by the Demokrat Party, is how the political representation of women in the party, and there are 4 factors that lead to this, first the decline in electability of the Demokrat Party, which is due to the end of SBY's presidential nomination and the bad image of the demokrat party is due to the fact that Demokrat's cadres are involved in corruption cases, which makes the community less sympathetic to the party. Furthermore, the absence of women was given a high ranking party number in the electoral district the third lack of active women in the campaign and the last lack of socialization about the 2014 legislative elections and so was the socialization of female candidates. The purpose of this study is to look at the factors that influence the political representation of women in the Demokrat party in the 2014 legislative elections at the West Sumatra level. In this study, researchers used a qualitative method with a case study approach.
\end{abstract}

Keywords: Political Representation ; Representation of Women ; Pemilu 2014 


\section{PENDAHULUAN}

Negara Indonesia adalah negara kesatuan dengan perwujudan bentuk negara demokrasi, Demokrasi adalah konsep sistem yang dapat mewadahi keinginan banyak orang terhadap sebuah tindakan dan pilihan, itu pun tidak terlepas dari perlindungan hak-hak asasi manusia. ${ }^{1}$ Demokrasi berdasarkan cara penyaluran kehendak rakyat, merupakan sistem politik demokrasi dapat dibedakan menjadi tiga macam, yaitu demokrasi langsung, demokrasi perwakilan atau demokrasi representatif, dan demokrasi perwakilan sistem referendum.

Setiap organisasi manusia yang memenuhi kriteria di atas secara material dan substansial dapat dianggap sebagai partai politik. Partai politik juga memiliki fungsi untuk melakukan rekrutmen terhadap orang-orang yang berkualitas yang diusung menjadi calegnya, karena kualitas caleg akan berpengaruh kepada kualitas Parlemen. Partai politik akan membutuhkan kader-kader untuk membangun partai politiknya menduduki kursi pemerintahan. Baik di eksekutif maupun legislatif. Selain untuk tingkatan seperti itu partai politik juga berkepentingan memperluas atau memperbanyak keanggotaan. Maka ia pun berusaha menarik sebanyak-banyaknya orang untuk menjadi anggotanya melalui sebuah rekruitmen.

Dalam implementasi kedaulatan masyarakat, mekanisme demokrasi yang sangat luas yaitu pelaksanaan pemilu.Pasal 6A Ayat 2 Perubahan Ketiga UUD 1945 menyatakan": "Pasangan calon Presiden dan Wakil Presiden diusulkan oleh partai politik atau gabungan partai politik peserta pemilihan umum sebelum pelaksanaan pemilihan umum." Sedangkan pada Pasal 18 Ayat 4 Perubahan Kedua UUD 1945 menegaskan: "Gubernur, Bupati, dan Walikota masing-masing sebagai kepala pemerintah daerah provinsi, kabupaten, dan kota dipilih secara demokratis." Dalam konsiderans huruf di UU Nomor 2 Tahun 2008 tentang partai politik menyebutkan bahwa partai politik merupakan sarana partisipasi politik masyarakat dalam mengembangkan kehidupan demokrasi untuk menjunjung tinggi kebebasan yang bertanggung jawab. ${ }^{3}$

Dalam partai politik harus juga memberikan keterwakilan politik perempuan yaitu dengan diterapkannya Affirmative Action, afrimatif action adalah sebuah tindakan khusus yang merupakan semacam pemaksaan untuk pemerataan dalam suatu kelompok yang mengalami diskriminasi. Ada beberapa definisi untuk istilah ini, yang sebagian besar mengandung pengertian yang terkait pada masalah diskriminasi ras, sesuai dengan

\footnotetext{
${ }^{1}$ Robert Dahl, Perihal Demokrasi : Menjelajahi Teori Dan Praktek Demokrasi Secara Singkat, Jakarta: yayasan obor Indonesia. Hal: 22

2 Buku UUD 1945 dan perubahannya .Jakarta.Gramedia 2009. Hal 12

${ }^{3}$ Rully Chairul Azwar.2008.Pengembangan SDM Partai Politik: Rekrutmen dan Kaderisasi di Partai Golkar.PUSKAPOL FISIP UI, Jakarta, . http://parlemen.net (.aksespukul 08.00 tanggal 18-07-19
} 

diskriminasi ras. ${ }^{4}$

Kebijakan Affirmative Action banyak dilakukan pada masalah pendidikan,pembangunan pemerintahan, pekerjaan, atau kesejahteraan sosial. Affirmative action dimulai sebagai koreksi dari pemerintahan dan ketidakadilan sosial yang lampau terhadap sekelompok orang. Kelompok ini biasanya dibedakan berdasarkan ras, gender atau budaya. Dalam partai politik pun mempunyai kewajiban menurut affirmative actionmenyatakan bahwa "setiap partai politik wajib mencalonkan lebih 30\% keterwakilan perempuan dalam pemilihan legislatif " hal tersebut dilakukan demi mengangkat partisipasi perempuan dalam politik. Karena banyaknya perempuan yang mampu dalam menjalankan perpolitikan di Indonesia.

Sepanjang pemilu dalam keterwakilan perempuan memiliki angka yang relatif turun naik. Keterwakilan politik perempuan pada pemilu legislatif di Sumatera Barat bisa dikatakan jauh mencapai kuota 30\%. Partai Politik belum bisa sepenuhnya mencukupi kuota pencalonan keterwakilan perempuan. Pada pemilu 2004 untuk keterwakilan perempuan pada pemilihan legislatif 2004 di Sumatera Barat yang memperoleh kursi sebanyak 5 kursi untuk duduk di DPRD Sumbar Barat dan untuk pemilihan legislatif 2009 memperoleh kursi 7 kursi, dan pada tahun 2014 itu memperoleh kursi sebanyak 6 untuk duduk di DPRD Sumatera Barat.

Tabel 1.

Daftar Asal Partai Anggota Legislatif Perempuan pada Pemilu 2004-2009-2014 Sumatera Barat

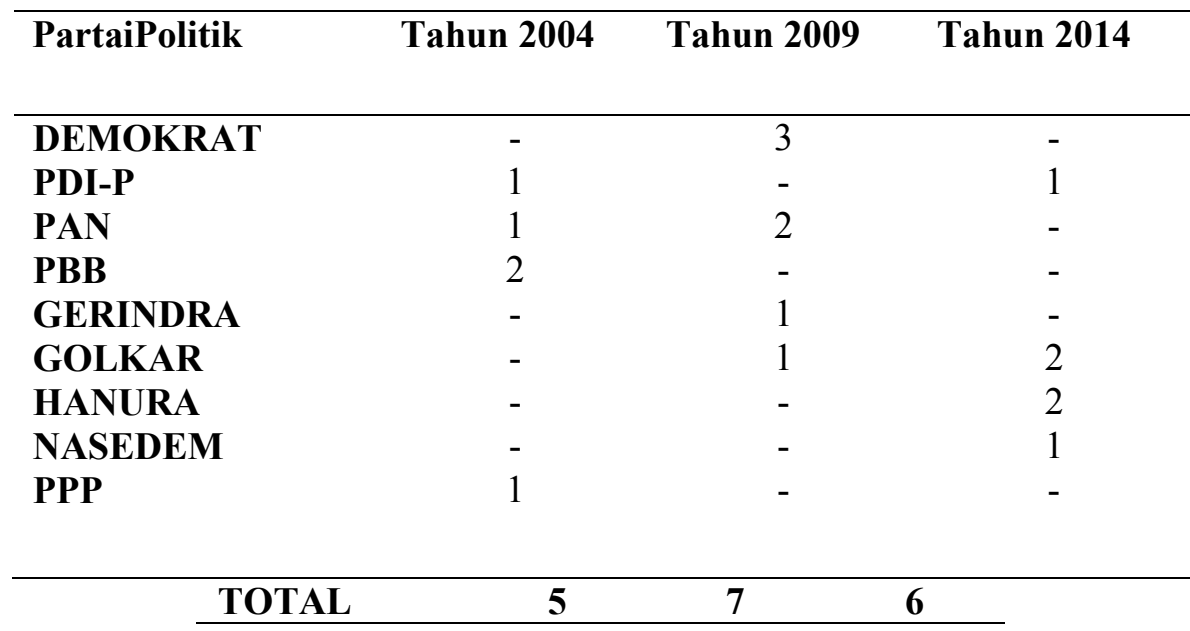

Sumber : diolah oleh peneliti dari KPU Sumbar

Dalam tabel di atas, dari tahun 2004 ke tahun 2009 mengalami peningkatan dengan bertambahnya 2 kursi di DPRD Sumatera Barat namun pada tahun 2014 kembali

\footnotetext{
${ }^{4}$ Safitri,2007 “Affirmative action30\% Kouta Caleg Perempuan Sebuah Semboyan?, Jurnal pisikologi Universitas Indonesia Esa Unggul, Hal.69 akses tgl 18-07-19 pukul 10.00 wib
} 
mengalami penurunan 1 kursi. Dalam tabel tersebut terlihat tidak adanya konsisten partai politik yang terus ada keterwakilan politik perempuannya yang berhasil duduk di DPRD Sumatera Barat. Selanjutnya, banyaknya partai politik baru yang berhasil menghasilkan keterwakilan politik perempuan pada DPRD Sumatera Barat, seperti partai politik Demokrat, Gerindra, Hanura dan Nasdem. Masing-masing partai politik telah menyumbangkan keterwakilan politik perempuan untuk memperoleh kursi dalam parlemen tingkat Sumatera Barat walaupun beberapa partai politik tidak berhasil mempertahankan hal tersebut salah satunya yaitu partai politik Demokrat.

Partai Demokrat didirikan pada September tahun 2001, dimana partai ini didirikan untuk mendukung Bapak Susilo Bambang Yudhoyono. ${ }^{5}$ Perolehan suara dalam pemilihan calon wakil Presiden dan hasil polling publik menunjukkan adanya popularitas terhadap individu Susilo Bambang Yudhoyono (selanjutnya disebut SBY), beberapa orang terpanggil nuraninya untuk memikirkan bagaimana sosok SBY bisa dibawa menjadi Pemimpin Bangsa dan bukan direncanakan untuk menjadi Wakil Presiden RI tetapi menjadi Presiden RI untuk masa mendatang. Bapak SBY sebagai ketua partai berhasil menjadi presiden RI dalam tahun 2004 pertama kalinya namun dalam perempuan demokrat terpilih belum berhasil dalam figur SBY tersebut. Selanjutnya pada pemilu tahun 2009 SBY terpilih kembali. Periode kedua untuk menjadi presdien RI dan memberikan dengan konsekuensi figur SBY partai politik demokrat merupakan partai politik no 1 dan di dikut dengan peroleh suara perempuan sebnyak 3 kursi dalam DPRD Sumatera Barat. namun pada pemilu 2014 SBY tidak boleh lagi mencalonkan dikarenakan sudah 2 kali periode tapi hal itu juga mempengaruhi rendahnya suara politik partai demokrat dan hilangnya perempan terpilih dalam pemilu legisatiif tahun 2014 di tingkat Sumbar.

Partai Demokrat di Sumatera Barat pada awal pencalonan Bapak SBY sebagai presiden juga membawa nama partai demokrat yang dikenal luas di Sumatera Barat. Hal ini diikuti pada tahun 2011 telah diangkatnya Bapak H. Josrizal Zein sebagai DPD partai politik demokrat yang terpilih menjadi Wali Kota Payakumbuh. Selanjutnya pada tahun 2018 diadakannya Musyawarah Daerah (Musda) III dan juga Muscab partai politik demokrat dimana yang terpilih adalah Bapak H. Mulyadi sebagai ketua DPD partai demokrat Sumatera Barat yang baru.

Dalam pemilu legislatif di Sumatera Barat pada tahun 2009, partai politik demokrat berhasil menduduki 3 perempuan untuk duduk di DPRD Sumatera Barat. Hal tersebut bisa disebut bisa dipandang sebuah pencapaian besar bagi partai baru yang berhasil mendudukan 3 perempuan partai politik demokrat dalam keterwakilan politik pada tingkat DPRD Sumatera Barat. Namun sebaliknya yang terjadi, pada pemilu tahun 2014 hilangnya keterwakilan politik perempuan partai politik demokrat ditingkat Sumatera Barat.

\footnotetext{
${ }^{5}$ di kutip dari web resmi Partai Demokrat www.demokrat.co.id di akses tgl 18-07-19 pkl 11.21 wib
} 
Penurunan suara yang diperoleh oleh Partai Demokrat ini, merupakan asumsi yang diangkat untuk menjelaskan bahwasanya awal penurunan suara tersebut terjadi pada pemilu tahun 2014, dimana Bapak SBY tidak lagi mencalonkan dirinya sebagai Presiden RI. Partai politik demokrat sangat kuat dibawah pengaruh kuat figur Bapak SBY sebagai ketua partai. Lebih jelasnya lagi pada tahun 2009 pada saat SBY mencalonkan kedua kalinya menjadi presiden RI dan berhasil menjadi presiden RI dan juga terpilihnya 3 perempuan dalam pemilu leguslatif tahun 2009 tingkat Sumatera Barat.

Pemilu Legislatif 2014 diselenggarakan atas dasar UU No. 8 Tahun 2012 tentang Pemilihan Umum Anggota DPR,DPD, dan juga DPRD yang merupakan revisi dari No. 10 Tahun 2008. Kecuali dalam peningkatan persentase ambang batas parlemen agar dapat duduk di DPR dari 2,5 menjadi 3,5 persen, dan juga perubahan mekanisme penetapan perolehan kursi partai politik dari tiga tahap menjadi dua tahap, hampir tidak ada perubahan mendasar lain yang diamanatkan UU Pemilu Legislatif 2014 dibandingkan UU sebelumnya. Di luar UU Pemilu, kerangka hukum lain yang mendasari penyelenggaraan Pemilu Legislatif 2014 adalah berbagai Keputusan KPU yang tidak lain merupakan operasionalisasi dan atau penjabaran dari berbagai ketentuan yang diatur dalam UU No. 8 Tahun 2012.

Sistem Pemilu Legislatif 2014 menggunakan sistem perwakilan proporsional daftar terbuka dengan mekanisme suara terbanyak. Problematik yang muncul di balik berlakunya kembali sistem proporsional daftar terbuka dengan mekanisme suara terbanyak adalah, pertama, mengerasnya konflik antar calon anggota legislatif di dalam internal partai politik dari Dapil yang sama. Para caleg partai politik di Dapil yang sama bersaing saling memperebutkan suara konstituen dengan berbagai cara, termasuk dengan cara membeli dukungan dari para pemilih.

Sistem pemilu yang telah berlaku sejak 2009 tersebut juga berdampak pada munculnya problematik kedua, yakni semakin intens dan masifnya politik uang yang dilakukan para caleg dalam rangka meraih dukungan sebesar-besarnya dalam Pemilu Legislatif 2014 yang lalu. Pemilu dilaksanakan dua tahap, yakni memilih anggota parlemen (pemilihan legislatif; pileg) dan memilih presiden dan wakil presiden (pemilihan presiden; pilpres). Pemilu Legislatif dilaksanakan lebih awal, karena partai politik yang memenuhi persyaratan tertentu berhak mengajukan kandidat presiden dan wakil presiden pada pilpres tiga bulan kemudian. Pemilu legislatif tahun 2014 menggunakan sistem pemilu proporsional terbuka, dalam sistem pemilu proposional terbuka mengakibatkan para calon legislatif akan lebih ketat dalam mencari suara terbanyak untuk mendapatkan kursi dalam parlemen.

\section{Partai Politik}

Pengertian Partai Politik

Partai Politik menurut Carl J. Friedrich bahwa sekelompok manusia yang terorganisir secara stabil dengan tujuan merebut atau mempertahankan penguasaan 
terhadap pemerintahan bagi pimpinan partainya dan berdasarkan pengusaha ini, memberikan kepada anggota partainya kemanfaatan yang bersifat idiil dan materiil. ${ }^{6}$ Dalam sebuah negara demokrasi partai politik suatu wadah bagi masyarakat untuk menyalurkan partisipasinya terhadap perkembangan atau jalannya negara. Partai politik suatu organisasi yang bertujuan dalam masuk ke lingkungan pemerintahan suatu negara. Partai politik memiliki fungsi bagi negara demokrasi sebagai sarana komunikasi politik, sebagai sarana pengaturan konflik dan sarana rekruitmen politik. $^{7}$

Fungsi Partai Politik

Pertama sebagai sarana komunikasi politik adalah fungsi menyalurkan aneka ragam pendapat dan aspirasi masyarakat dan mengaturnya sedemikian rupa sehingga kesimpangsiuran pendapat dalam masyarakat berkurang. Kedua, sarana sosialisasi adalah fungsi sebagai proses melalui mana seseorang memperoleh sikap dan orientasi terhadap fenomena politik yang umumnya berlaku dalam masyarakat dimana ia berada. Ketiga sarana rekrutmen politik adalah fungsi ini berkaitan dengan masalah sileksi kepemimpinan, baik kepemimpinan internal partai maupun kepemimpinan nasional yang lebih luas. keempat sebagai sarana pengatur konflik adalah funsi sebagai membantu mengatasinya, atau dapat mengatur sedemikian rupa sehingga akibat negatifnya dapat ditekan seminimal mungkin.

\section{Afrimative Action \\ Afrimative Action Dan Partai Politik}

Sistem kuota $30 \%$, calon legislatif perempuan telah berhasil diwujudtan pertama kali ke dalam UU No. 12 tahun 2003 tentang pemilihan umu anggota DPR, DPRD, DPD. Kemudian berlanjut pada pemilu tahun 2009 yang tertuang dalam UU No 10 tahun 2008 dan kemudian pada UU No 8 tahun 2012 tetang pemilihan umum Anggota DPR, DPRD, DPD yang menjadi salah satu dasar penyelenggaraan pemilu tahun $2014{ }^{8}$ Apabila partai politik peserta pemilu 2014 tidak dapat memenuhi kuota 30\% keterwakilan perempuan di setiap tingkatan maka partai politik tersebut dinyatakan tidak memenuhi persyaratan pengajuan bakal calon pada daerah pemilihan yang tidak memenuhi kuota 30\% keterwakilan perempuan.Artinya, daerah pemilihan suatu partai politik akan dihapuskan apabila tidak memenuhi kuota 30\% keterwakilan perempuan walaupun bakal calon lain partai politik dalam daerah pemilihan tersebut dinyatakan memenuhi persyaratan.Konsekuensi dari kebijakan KPU inilah yang pada akhirnya menimbulkan kontroversi. ${ }^{9}$

Aturan tentang kewajiban kuota $30 \%$ bagi caleg perempuan adalah salah satu capaian penting dalam perjalanan demokrasi Indonesia pasca reformasi. Aturan tersebut

\footnotetext{
${ }^{6}$ Mariam Budiarjo, Edisi Revisi Dasar-dasar Ilmu Politik, Jakarta : Gramedia, 2008, hlm 404

${ }^{7}$ Ibid hal 405

${ }^{8}$ Skripsi Uin-Alaudin Judul Affirmatif Action Partai Dalam Pencalonan Politisi Perempuan DPRD Kota Makasar Oleh Nurul Fadliyah.J http;//repository.uin-alauddin.ac.id/4680/1/nurul\%fadliyah\%20J.pdf

${ }^{9}$ Op.Cit, Miriam Budiardjo, hal.16
} 

No. 12 Tahun 2003 tentang Pemilihan Umum, UU No. 2 Tahun 2008 tentang Partai Politik dan UU No.10 Tahun 2008 tentang Pemilihan Umum Anggota DPR-DPRD yang di dalamnya juga memuat aturan terkait Pemilu tahun 2009. UU No. 2 Tahun 2008, mengamanahkan pada partai politik untuk menyertakan keterwakilan politik perempuan minimal 30\% dalam pendirian maupun kepengurusan di tingkat pusat. Angka 30\% ini didasarkan pada hasil penelitian PBB yang menyatakan bahwa jumlah minimum $30 \%$ memungkinkan terjadinya suatu perubahan dan membawa dampak pada kualitas keputusan yang diambil dalam lembaga publik. UU No. 10 Tahun 2008 mewajibkan parpol untuk menyertakan 30\% keterwakilan politik perempuan pada kepengurusan tingkat pusat.Syarat tersebut harus dipenuhi partai politik agar dapat ikut serta dalam Pemilu.

\section{Teori Representasi}

Hanna Fenichel Pitkin (1967) mengemukakan bahwa representasi merupakan bentuk modern dalam demokrasi. Dalam konsepsi Pitkin, setidaknya ada empat cara memandang representasi politik. ${ }^{10}$ Secara mendasar Hanna Pitkin memberikan kategorisasi yang ideal bagi representasi politik, melalui representasi simbolik, representasi formalistik,representasi deskriptif dan representasi substantif.

Pertama,perspektif formalistik, melihat bahwa representasi merupakan pemberian dan pemilikan kewenangan oleh wakil sebagai orang yang diberi kewenangan untuk bertindak. Pandangan otoritas ini memusatkan pada formalitas hubungan dalam sebuah organisasi formal. Kedua, representasi deskriptif yaitu seseorang dapat berpikir dalam kerangka sebagai "standing for" segala sesuatu yang tidak ada. Wakil bisa berdiri demi orang lain yang diawakili, menjadi substitusi untuk orang lain, atau mereka cukup menyerupai orang lain. Representasi deskriptif menggambarkan bahwa wakil mendeskripsikan konstituen, biasanya ditandai dengan karakteristik yang Nampak seperti warna kulit, gender, atau kelas sosial. Model ini dipahami sebagai kesamaan deskriptif antara wakil dengan yang diwakili.

Ketiga, representasi simbolik berarti mempresentasikan sesuatu yang bukan merepresentasikan fakta. Ide person dapat direpresentasikan tidak dengan peta atau potret, tetapi dengan simbol, dengan disimbolkan atau diwakili secara simbolik. Meskipun sebuah simbol merepresentasikan "standing for" segala sesuatu, tetapi tidak menyerupai apa yang diwakili. Simbol memiliki ciri yang membantu merasionalisasi signifikansi simboliknya, sehingga simbol mensubstitusi yang diwakili dan simbol mensubstitusi apa yang disimbolkan. Keempat, representasi substantive yaitu terepresentasinya ide dan kepentingan perempuan dalam formulasi kebijakan, artinya

\footnotetext{
${ }^{10}$ www. Journal Unair.ac.id, Dwi Windyastuti, Politik Representasi Perempuan, 31-07-2019 pkl 21:22 WIB
} 
representasi substantif ketika representator membawa kepentingan "ide" represented ke dalam area kebijakan publik. ${ }^{11}$

\section{Rekruitmen Politik}

Rekrutmen politik adalah salah satu dari fungsi partai politik yang merupakan suatu proses untuk mencari dan menyeleksi anggota untuk kegiatan regenerasi dari sebuah organisasi, baik partai politik, lembaga pemerintahan maupun organisasi lainnya. ${ }^{12}$ Namun, rekrutmen lebih dikenal dalam bahasa politik seperti yang terdapat dalam buku Dasar-Dasar Ilmu Politik yang menyebutkan: “...proses mencari dan mengajak orang yang berbakat untuk turut aktif dalam kegiatan politik sebagai anggota partai..."

Istilah rekrutmen lebih dikenal dalam bahasa perpolitikan, dan kemudian diadopsi oleh partai politik seiring dengan kebutuhan partai akan dukungan kekuasaan dari rakyat, dengan cara mengajak dan turut serta dalam keanggotaan partai tersebut. Rekrutmen sendiri memiliki acuan waktu dalam prosesnya, maka pada saat itu pula rekrutmen dilakukan pada saat partai memerlukan Pendwfapat lainnya yang mengemukakan pengertian rekrutmen politik oleh Ramlan Surbakti dalam buku Memahami Ilmu Politik yang dimaksud rekrutmen politik adalah: "Seleksi dan pemilihan atau seleksi dan pengangkatan seseorang atau sekelompok orang untuk melaksanakan sejumlah peranan dalam sistem politik pada umumnya dan pemerintahan

Pada khususnya,dengan mengkhususkan kepada orang-orang yang mempunyai bakat yang cukup menonjol, partai politik menyeleksi dan menempatkannya sebagai seorang calon pemimpin"Rekrutmen politik partai dari beberapa penjelasan di atas dapat disimpulkan sebagai ajang untuk mencari dan menyeleksi keanggotaan baru untuk diikutsertakan dalam partai politik sebagai pembelajaran politik, di samping untuk melakukan regenerasi dalam partai politik tersebut maka dilakukan melalui mekanisme yang diterapkan oleh partai.Pengaruh rekrutmen politik sangat menentukan dalam regenerasi kehidupan partai.Hal itu dikarenakan partai memerlukan penyegaran keanggotaan untuk dapat bertahan dalam mempertahankan kekuasaan politiknya di mata masyarakat.

Adapun mekanisme rekrutmen politik partai yang dikemukakan oleh Rush dan Althoff adalah: “...proses pengrekrutan politik memiliki dua sifat yaitu: (1) sifat tertutup; adalah suatu sistem pengrekrutan administratif yang didasarkan atas patronase. (2) sifat terbuka; adalah sistem yang berdasarkan pada ujian-ujian terbuka". ${ }^{13}$ Proses pengrekrutan partai memiliki sifat khusus dalam tafsirannya, misalnya untuk pengrekrutan administratif diperlukan suatu dasar patronase (lindungan) dalam proses pengrekrutannya, dalam arti faktor kedekatan seseorang dapat dijadikan acuan untuk memperoleh pengaruh terutama ketika proses pemilihan pemimpin partai. Rekrutmen

\footnotetext{
${ }^{11}$ www. Journal Unair.ac.id, Dwi Windyastuti, Politik Representasi Perempuan, 31-07-19 pk1 21:22 WIB

${ }^{12}$ Ramlan subaktik. Memahami ilmu politik. Jakarata. PT Grasindo 1992 hal 150

${ }^{13}$ Michael Rush, Phillip Althoff, 2007,Pengantar Sosiologi Politik, Alih Bahasa oleh Kartini Kartono, Jakarta: PT Raja Grafindo Persada, Hal:247.
} 

politik meliputi aspek subyek politik dalam arti manusia, dan obyek politik dalam arti partai politik. Rekrutmen politik partai dapat dilakukan dengan cara-cara yang diinginkan partai baik secara terbuka maupun tertutup. Proses pengrekrutan partai memiliki sifat khusus dalam tafsirannya, misalnya untuk pengrekrutan administratif diperlukan suatu dasar patronase (lindungan) dalam proses pengrekrutannya, dalam arti faktor kedekatan seseorang dapat dijadikan acuan untuk memperoleh pengaruh terutama ketika proses pemilihan pemimpin partai. Rekrutmen politik meliputi aspek: subyek politik dalam arti manusia, dan obyek politik dalam arti partai politik. Rekrutmen politik partai dapat dilakukan dengan cara-cara yang diinginkan partai baik secara terbuka maupun tertutup.

Sistem rekrutmen politik menurut Rush dan Althoff dibagi menjadi dua cara. Pertama rekrutmen terbuka, yakni dengan menyediakan dan memberikan kesempatan yang sama bagi seluruh warga negara untuk ikut bersaing dalam proses penyeleksian. Dasar penilaian dilaksanakan melalui proses dengan syarat-syarat yang telah ditentukan melalui pertimbangan-pertimbangan yang objektif rasional. Dimana setiap orang yang memenuhi syarat untuk mengisi jabatan politik yang dipilih oleh rakyat mempunyai peluang yang sama dalam melakukan kompetisi. Kedua, rekrutmen tertutup yaitu adanya kesempatan untuk masuk menduduki jabatan politik tidaklah sama setiap warga negara artinya hanya individu-individu tertentu yang dapat menduduki jabatan politik

Penulis dalam penelitian ini mengambil indikator dari Michael Rush dan Phillip Althoff, dalam penjelasan tahapan rekrutmen politik pemimpin. Maka penulis dalam melakukan penelitian ini merumuskan operasionalisasi konsep rekrutmen politik Caleg oleh DPD Partai Demokrat Sumbar pada caleg perempuan pada 2019- 2024.

1) Penyediaan rekrutmen politik terhadap Caleg perempun, merupakan tahapan awal yang dilakukan Partai Demokrat dalam pengrekrutan Caleg melalui:

a) Mekanisme rekrutmen Caleg perempuan yang dilakukan Partai.

b) Waktu dan tempat pelaksanaan rekrutmen Caleg perempuan.

c) Sarana rekrutmen Caleg perempuan.

2). Kontrol rekrutmen politik Caleg, merupakan peran yang dilakukan DPD Partai Demokrat dalam mengontrol jalannya rekrutmen Caleg. Adapun pelaksanaan kontrol rekrutmen politik dilakukan pada: ${ }^{14}$

a) Bakal calon Legislatif dari internal partai.

b) Bakal calon Legislatif dari eksternal partai.

\section{METODE PENELITIAN}

Jenis pendekatan penelitian yang digunakan adalah kualitatif dengan menggunakan metode studi kasus. Metode studi kasus adalah salah satu dari metode penelitian ilmu-ilmu sosial yang lebih cocok bila pertanyaan penelitiannya berkenaan

\footnotetext{
${ }^{14}$ Ibid hal 247
} 

dengan "How atau Why", bila peneliti hanya memiliki sedikit peluang untuk mengontrol peristiwa-peristiwa yang akan diselidiki dan bilamana fokus penelitiannya terletak pada fenomena kontemporer di dalam kehidupan nyata. ${ }^{15}$ Karena pertanyaan penelitian yang penulis ajukan adalah "Bagaimana" danpeneliti tidak memiliki peluang untuk mengontrol peristiwa-peristiwa yang akan diselidiki serta fokus penelitian ini adalah fenomena kontemporer, maka peneliti memutuskan untuk memakai metode ini. Studi kasus merupakan penelitian yang intensif, terintegrasi dan mendalam.

Tujuan untuk mengembangkan pengetahuan yang mendalam dengan menelusuri mengenai objek kajian, dengan sifat eksploratif. Mendalam secara longitudinal (pengumpulan dan analisis data dalam jangka waktu tertentu). Tipe studi kasus ini dipakai untuk menjelaskan bagaimana representasi politik perempuan pada partai demokrat pada pemilu leislatif di Sumbar. Jika penelitian ini sudah terfocuskan pada suatu masalah, diharapkan mampu mengungkapkan berbagai informasi lain yang dibutuhkan peneliti secaramendalam. Hal inilah yang menjadi alasan dasar peneliti memilih menggunakan metode studi kasus.

\section{HASIL dan PEMBAHASAN}

Kesetaraan gender sangat diperlukan pada masa saat ini apalagi dalam perpolitikan. Dalam berpolitik kesetaraan gender sudah diatur oleh pemerintah yaitu adanya affirmative action. Metode Affirmative Action untuk menjamin keterwakilan politik perempuan dapat dilakukan beragam. Dua di antaranya yang paling utama adalah kuota yang ditetapkan melalui konstitusi atau peraturan perundang-undangan, dan kuota melalui partai politik. ${ }^{16}$

Dalam Undang-Undang Kebijakan kuota 30\% keterwakilan perempuan dalam PKPU No. 7 Tahun 2013 memberikan konsekuensi kepada partai politik peserta pemilu 2014 untuk memenuhi kuota 30\% keterwakilan perempuan berdasarkan alokasi kursi pada setiap daerah pemilihan Anggota DPR, DPRD Provinsi, dan DPRD Kabupaten/Kota. Apabila partai politik peserta pemilu 2014 tidak dapat memenuhi kuota 30\% keterwakilan perempuan di setiap tingkatan maka partai politik tersebut dinyatakan tidak memenuhi persyaratan pengajuan bakal calon pada daerah pemilihan yang tidak memenuhi kuota 30\% keterwakilan perempuan Artinya, daerah pemilihan suatu partai politik akan dihapuskan apabila tidak memenuhi kuota 30\% keterwakilan perempuan walaupun bakal calon lain partai politik dalam daerah pemilihan tersebut dinyatakan memenuhi persyaratan. ${ }^{17}$

Aturan tentang kewajiban kuota $30 \%$ bagi caleg perempuan adalah salah satu capaian penting dalam perjalanan demokrasi Indonesia pasca reformasi. Aturan tersebut tertuang dalam sejumlah UU, yakni UU No. 31 Tahun 2002 tentang Partai Politik, UU

\footnotetext{
${ }^{15}$ Robert K. Yin, 2005,Studi Kasus Design \& Metode, Jakarta: Rajawali Pers,hlm 10-11. 35 Bagia, Waluya. 2007. Sosiologi: Menyelami Fenomena Sosial di Masyarakat. Bandung: Purna Inves. Hal: 9

${ }^{16}$ Opcit Puskapol, hal 1-2

${ }^{17}$ Opcit Miriam Budiardjo. Hal.16
} 
No. 12 Tahun 2003 tentang Pemilihan Umum, UU No. 2 Tahun 2008 tentang Partai Politik dan UU No.10 Tahun 2008 tentang Pemilihan Umum Anggota DPR-DPRD yang di dalamnya juga memuat aturan terkait Pemilu tahun 2009.

UU No. 2 Tahun 2008 mengamanahkan pada parpol untuk menyertakan keterwakilan perempuan minimal 30 dalam pendirian maupun kepengurusan di tingkat pusat. Angka 30\% ini didasarkan pada hasil penelitian PBB yang menyatakan bahwa jumlah minimum 30\% memungkinkan terjadinya suatu perubahan dan membawa dampak pada kualitas keputusan yang diambil dalam lembaga publik. UU No. 10 Tahun 2008 mewajibkan parpol untuk menyertakan 30\% keterwakilan perempuan pada kepengurusan tingkat pusat.Syarat tersebut harus dipenuhi parpol agar dapat ikut serta dalam Pemilu. Peraturan lainnya terkait keterwakilan perempuan tertuang dalam UU No. 10 Tahun 2008 Pasal ayat 2 yang mengatur tentang penerapan zipper system, yakni setiap 3 bakal calon legislatif, terdapat minimal satu caleg perempuan. UU ini menegaskan eksistensi perempuan untuk menuntun kiprahnya ke panggung politik.

Penelitian ini berfokuskan kepada faktor-faktor yang menyebabkan hilangnya keterwakilan perempuan pada pemilu legislatif tahun 2014 yang dimana pertama melihat bagaimana rekruitmen yang dilkukan oleh partai demokrat dan juga melihat representasi politik perempuan di partai demokrat di tingkat Sumbar sehingga dengan melihat hal tersebut akan dilanjutkan untuk menegetahui apa saja faktor penurunan suara perempuan pada pemilu legislatif 2014 yang dimana pada pemilu 2014 ini keterwakilan perempuan dalam pencalonan menjadi calon legislatif sudah memenuhi angka 30\% di daerah pemilihan masing-masing sedangkan dalam hasil pemilu legislatif 2014 perempuan tidak berhasil meraih angka 30\% dalam DPRD Provinsi. Partai demokrat tidak mendapatkan kursi di DPRD Provinsi untuk kaum perempuan yang dimana pada pemilu sebelumnya partai demokrat berhasil menduduki 3 kursi di DPRD Provinsi.

Dalam hal tersebut banyaknya faktor yang dapat dilihat bagaimana representasi perempuan partai Demokrat pada pemilu 2014 seperti factor dari Pola Rekrutmen yang dilakukan oleh partai Demokrat dalam menyaring perempuan untuk dapat bergabung dalam pemilu legislatif 2014. Yang dimana mekanisme rekrutmen politik partai yang dikemukakan oleh Rush dan Althoff adalah: “...proses pengrekrutan politik memiliki dua sifat yaitu: (1) sifat tertutup; adalah suatu sistem pengrekrutan administratif yang didasarkan atas patronase. (2) sifat terbuka; adalah sistem yang berdasarkan pada ujianujian terbuka". ${ }^{18}$ Proses pengrekrutan partai memiliki sifat khusus dalam tafsirannya, misalnya untuk pengrekrutan administratif diperlukan suatu dasar patronase (lindungan) dalam proses pengrekrutannya, dalam arti faktor kedekatan seseorang dapat dijadikan acuan untuk memperoleh pengaruh terutama ketika proses pemilihan pemimpin partai. Rekrutmen politik meliputi aspek: subjek politik dalam arti manusia, dan obyek politik dalam arti partai politik. Rekrutmen politik partai dapat dilakukan dengan cara-cara

\footnotetext{
${ }^{18}$ Opcit Michael Rush, Phillip Althoff, 2007.Hal:247.
} 
yang diinginkan partai baik secara terbuka maupun tertutup. Selain dilihat dari pola rekruitmen seperti apa yang digunakan oleh partai Demokrat dapat juga dilihat juga bagaimana representasi perempuan dalam partai Demokrat Tersebut. Bisa dikatakan apa saja yang telah dilakukan perempuan dalam partai tersebut.

Mencoba menggunakan konsep Representasi Hanna Fenichel Pitkin (1969) yang mengemukakan bahwa representasi adalah layak dalam politik modern. Hanna Pitkin melalui bahasan konsep representasi, melihat setidaknya ada empat cara memandang representasi politik. ${ }^{19}$ menurut hanna pitkin memiliki empat indikator dalam melihat perempuan di keterwakilan politik yaitu adanya teori formalistik berpusat pada otorisasi yang berada dalam struktur formal yang merepresentasikan berbagai kehendak. ${ }^{20}$

Kedua adanya representasi deskriptif yang dalam prakteknya seorang representasi mampu membela atau mengadvokasi kelompok yang memiliki karakter atau wajah politik yang sama. Sedangkan yang ketiga,disebut sebagai representasi simbolis yang pada saat representasi menghasilkan sebuah ide bersama, antara wakil dan terwakil. Terakhir representasi substantif dalam konteks ini menyebutkan ketika representasi membawa kepentingan ide-ide yang direpresentasikan dalam area kebijakan publik. ${ }^{21}$ Setelah melihat bagaimana perempuan pada partai tersebut. Atau untuk melihat untuk apa perempuan ada pada partai tersebut peneliti juga mendapatkan hasil faktor apa saja yang mempengaruhi suara perempuan turun pada pemilu 2014 di tingkat Provinsi tersebut. Dan dari hal tersebut juga akan melihat apa saja faktor terkait dalam hilangnya keterwakilan perempuan pada pemilu legislatif untuk duduk pada DPRD Sumatera Barat

\section{KESIMPULAN}

Negara Demokrasi menciptakan sebuah kesatuan yang tidak memandang adanya diskriminasi dalam masyarakat. menciptakan sebuah masyarakat yang mempunyai sebuah kesetaraan yaitu antara laki-laki dan perempuan. Dan juga mempunyai sebuah hak yang sama dimata hukum dan hak yang sama dalam terjun di perpolitikan. Dalam hal itu di perpolitikan untuk menunjang perempuan dalam perpolitikan pemerintahan memberikan sebuah kuota 30\% untuk perempuan mengisi tempat dalam calon legislatif di partai. Hal ini sangat menjunjung perempuan akan bangkit untuk maju di kancah perpolitikan.

Penelitian ini berfokuskan kepada faktor-faktor yang menyebabkan hilangnya keterwakilan perempuan pada pemilu legislatif tahun 2014 yang dimana pertama melihat bagaimana rekruitmen yang dilakukan oleh partai demokrat dan juga melihat representasi politik perempuan di partai demokrat di tingkat Sumbar sehingga dengan

\footnotetext{
${ }^{19}$ Opcit Journal Unair.ac.id, Dwi Windyastuti

${ }^{20}$ Papers presented in the workshop organized female political role on November 5, 2009 atplasa Surabya by the Center for Religious and Community Studies (CRCS)artikelpolitik Representasi

${ }^{21}$ HannaPitkin.2006."Political Representation,"dalamStanford Encyclopedia ofPhilosophy., pada tahun 2010.[diakses pada 23 juli 2019 pukul11.34WIB
} 
melihat hal tersebut akan dilanjutkan untuk menegetahui apa saja faktor penurunan suara perempuan pada pemilu legislatif 2014 yang dimana pada pemilu 2014 ini keterwakilan perempuan dalam pencalonan menjadi calon legislatif sudah memenuhi angka $30 \%$ di daerah pemilihan masing-masing sedangkan dalam hasil pemilu legislatif 2014 perempuan tidak berhasil meraih angka 30\% dalam DPRD Provinsi.

Rekrutmen politik, rekruitmen untuk calon legislatif yang dilakukan oleh partai demokrat peneliti melihat bahwa memang lebih pada pola rekrutmen yang terbuka. Yang dimana partai demokrat mendahulukan pengurus partai yang akan mengisi kursi calon legislatif tetapi juga tidak menutup kemungkinan bagi masyarakat umum untuk ikut serta. Tetapi dalam hal tersebut dengan membuka Rekrutmen secara terbuka mengakibatkan kurangnya kualitas dari para caleg tersebut karena dalam hal ini mengakibatkan caleg perempuan hanya dari partai politik demokrat hanya secara kuantitas tetapi kurang dengan kualitas caleg itu sendiri.

Representasi politik menurut Hanna Pitkin yang dimana memberikan 4 indikator yaitu formalistk, deskriptif, simbolik, dan substantif untuk melihat bagaimana perempuan partai demokrat yang juga calon perempuan legislatif pemilu tahun 2014 di partai demokrat. Hal ini menjawab kegiatan perempuan dalam partai, kegiatan perempuan untuk gendernya dan kegiatan perempuan untuk kesejahteraan masyarakat. Setelah melihat dari rekrutmen politiknya yang dimana nantinya dilihat representasi politik perempuan di partai demokrat yang dimana dari rekrutmen politiknya merupakan salah salah satu faktor yang mengaibatkan hilangnya ketrewakilan perempuan dalam partai karean dalam rekrutmen terbuka hanya untuk kuantitas tetapi tidak dengan kualitas dari caleg perempuan itu sendiri. Dan selanjutnya faktor yang membuat hilangnya keterwakilan perempuan partai demokrat untuk duduk di DPRD Sumatera Barat adanya 4 faktor yang mengakibatkan hal tersebut,salah satunya asumsi dari peneliti yaitu hialngnya SBY dalam pencalonan presiden membuat suara partai politik demokrat turun tingkat nasional dan juga mempengaruhi hilangnya keterwakilan perempuan pada pemilu legislatif tingkat Sumatera Barat pyang dimana hal ini dikategorikan karena turunnya elektablitas partai demokrat, yang juga salah satunya buruknya citra partai demokrat dikarenakan para kader demokrat dinasonal terlibat kasus korupsi yang dimana hal tersebut membuat masyakarat kurang simpati terhadap partai politik demokrat. Selanjutnya tidak adanya perempuan diberkan nomor urut partai tinggi dalam dapil masing-masing caleg perempuan partai politik demokrat. Selanjutnya kurang aktifnya perempuan dalam berkampanye dimana hal ini salah satu kurangnya cakupan tempat berkampanye. Terakhir kurangnya sosialsasi tentang pemilu legislatif 2014 dan begitu juga dengan sosalisasi terhadap caleg perempuan pemilu legislatif 2014 di Sumatera Barat baik dari pihak partai politik demokrat ataupun pihak bawaslu perempuan sangat jarang diperkenalkan dalam perpolitikan yang diikutinya hal tersebut membuat masyarakat tidak begitu mengenal sosok perempuan dalam perpolitikan. 
JDPL (Jurnal Demokrasi dan Politik Lokal)

Vol I Nomor 1, April 2019

DAFTAR PUSTAKA

\section{Buku}

Arbi Sanit, 1985.Perwakilan Politik Di Indonesia, Penerbit CV Rajawali, Jakarta

Ellya Rosana. 2012.Partai Politik Dan Pembangunan Politik Ejournal.Radenintan.Ac.Id/Index.Php/Tapis/Article/Download/1548/1288. 8(1).

Hanna Pitkin. 2006. "Political Representation," Dalamstanford Encyclopedia Ofphilosophy.Diakses Daricopye-Maildari Suzzane Dovi (Sdovi@U.Arizona.Edu.), Pada Tahun 2010

Ketut Putra Erawan, Riswanda Imawan Dkk.2010.Draft Modul Organisasi Dan ManajemenKepartaian: Bab I Manajemen Sumberdaya Manusia Politik.

Lexy J. Moleong.2004 Metode Penelitian Kualitatif, Bandung, PT.Remaja Rosdakarya.

Miriam Budiardjo.2008 Edisi Revisi Dasar-Dasar Ilmu Politik. Jakarta: PT Gramedia PustakaUtama.

Michael Rush,2007. Phillip Althoff,Pengantar Sosiologi Politik, Alih Bahasa Oleh KartiniKartono, Jakarta: Pt Raja Grafindo Persada.

Mudiyati Rahmatunnisa.2016. Affirmative Action Dan Penguatan Partisipasi Politik Kaum Perempuan IndonesiaJurnal.Unpad.Ac.Id/Wacanapolitik/Article/Download/11049/Pdf 1 (2).

Moh. Zamili. 2015.Menghindar Dari Bias:Praktik Trianggulasi Dan Kesahihan Riset Kualitatif. Jurnal Lisan Al-Hal.9 (2).

Papers Presented In The Workshop Organized Female Political Atplasa Surabaya By The Center For Religious And Community Studies (Crcs).2009.Artikelpolitik Representasi.

Puskapol,2009. Potret Ketrepilihan Perempuan di Legislatif pada Pemilu 2009, Jakarta, Puskapol Fisip UI.

Robert Dahl. Perihal Demokrasi : Menjelajahi Teori Dan Praktek Demokrasi Secara Singkat Jakarta: Yayasan Obor Indonesia.

Robert K.Yin.2014.Studi Kasus, Desain Dan Metode. Jakarta. PT. Raja Grafindo Persada. 2008

Sukandarrumidi, Haryanto. Dasar-Dasar Penulisan Proposal Penelitian. Gadjah MadaUniversity Press.

Safitri.2007.Affirmative Action30\% Kouta Caleg Perempuan Sebuah Semboyan?,Jurnal Pisikologi Universitas Indonesia Esa Unggul.5 (1). 
JDPL (Jurnal Demokrasi dan Politik Lokal)

Vol I Nomor 1, April 2019

\section{Internet}

Web Kpu Sumbar

Web Partai DemokratWww.Demokrat.Or.Id

Berita Metro Andalas Https://Www.Metroandalas.Co.Id/Berita-Mulyadi-TerpilihSecara-Aklamasi-Sebagai-Ketua-Dpd-Partai-Demokrat-Sumbar.Html ,

Asnan, Gusti, (2007), Memikir ulang regionalisme: Sumatra Barat tahun 1950-an, Yayasan Obor Indonesia, ISBN 978-979-461-640-6.

Rinaldy Sofwan Fakhrana (12 Mei 2015). "Sah, SBY Nakhodai Partai Demokrat Periode 2015-2020". CNNIndonesia.com. Diakses tanggal 18 Desember 2019

Peraturan Perundang - undangan

UU No. 10 Tahun 2008 Pasal Ayat 2

Undang-Undang No 2 Tahun 2008 Tentang Partai Politik Pasal 2 Ayat 5

UU No. 12 tahun 2003 pasal 65 Tentang Ketrwakilan Politik Perempuan 30\% 